Univerzitet u Beogradu
Poljoprivredni fakultet
Institut za poljoprivrednu tehniku
Naučni časopis
POLJOPRIVREDNA TEHNIKA
Godina XLVI
Broj 4., 2021.
Strane: $58-73$

\title{
A REVIEW OF NUTRIENT POTENTIALS OF COMPOSTED MUNICIPAL SOLID WASTES FOR AGRICULTURAL USE
}

\author{
Iniobong U. Udoumoh *1, Josiah M. Ayotamuno², Israel I. Ahuchaogu' \\ ${ }^{I}$ Department of Agricultural and Food Engineering, University of Uyo, Uyo, Nigeria. \\ ${ }^{2}$ Department of Agricultural Engineering, Rivers State University of Science and \\ Technology, Port Harcourt, Nigeria
}

\begin{abstract}
The article reviewed the application of compost to the plants in providing essential macro-nutrients such as Nitrogen $(\mathrm{N})$, Potassium (K) and Phosphorus (P), and micro-nutrients, ie. Iron (Fe), magnesium $(\mathrm{Mg})$, copper $(\mathrm{Cu})$, Zinc $(\mathrm{Zn})$, and Boron $(\mathrm{B})$ and enhances microbial activity. Nutrients are released slowly due to strong association of compost with organic matter. This property makes compost an excellent alternative to inorganic fertilizers as leaching and volatilization losses are reduced. Over-reliance on the use of chemical fertilizers has been associated with declines in soil physical and chemical properties and crop yield, and significant land problems, such as soil degradation due to over exploitation of land and soil pollution caused by high application rates of fertilizers and pesticide application. The reduction in the use of chemical fertilizers and supplementing the same through organic manure such as urban compost, otherwise known as municipal solid waste (MSW), Farm yard manure (FYM), poultry manure (PM), etc., become necessary to sustain productivity, profitability and to maintain soil health. Application of FYM is practiced for many years but it has become scarce due to scanty population of livestock, therefore urban compost is one of the alternative sources of organic manure.
\end{abstract}

Key words: Nutrients, organic matter, municipal solid waste, compost, crop yield

\footnotetext{
*Corresponding Author. E-mail: unwanaobong12@gmail.com
} 


\section{INTRODUCTION}

Municipal Solid Waste (MSW) compost contains a large fraction of organic N that could be potentially beneficial to agricultural soils. A typical MSW compost application of $20 \mathrm{t} / \mathrm{acre}$ ( $20 \mathrm{t} / \mathrm{ha}$ in EU) can contain from 300 to $500 \mathrm{lb} \mathrm{N} /$ acre (app. 10 to $25 \mathrm{~kg} \mathrm{~N} / \mathrm{ha}$ in EU). Land application of MSW compost has to be managed properly in order to optimize crop growth. Composting MSW involves managing environmental conditions to accelerate the biological oxidation of organic waste components resulting in a product with potential benefits for agricultural soils $[1,2]$.

Composting MSW is seen as a method of diverting organic waste materials from landfills while creating a product, at relatively low-cost, that is suitable for agricultural purposes [3, 4]. The trend may be accentuated by a combination of economic and environmental factors, aimed at reducing municipal landfill capacity; avert costs associated with land-filling and transportation of materials; adoption of legislation to protect the environment; minimizing the use of commercial fertilizers; increasing the capacity for the recycling of household waste, and so on. With rising interest in organic agriculture, the production of organic-grade MSW compost for agriculture is also gaining popularity because of its positive effect on biological, physical, and chemical soil properties [5].

[6] reported that waste materials, and materials derived from wastes, possess many characteristics that can improve soil fertility and enhance crop performance. These materials can be particularly useful as amendments to severely degraded soils associated with mining activities. The use of composted municipal solid waste contains high organic matter which can be absorbed by plants [7] and improves soil quality [8]. Soil organic matter consists of a variety of simple and complex carbon compounds and thus provides food for a variety of organisms. It provides much of the cation exchange and water-holding capacities of surface soils [9].

Municipal solid waste exerts a positive influence on physical and chemical soil properties such as porosity, aggregate stability, water holding capacity, cation exchange capacity, and releases nutrient generally [10]. However, there are concerns about potential public health hazards from the presence of pathogens and pollutants such as trace metals and organic contaminants [11]. Furthermore, the bioavailability of these non-essential heavy/trace metals could pose serious health and environmental problems to the inhabitants of the vicinity of the dumpsites.

\section{Physical and Chemical Properties of Waste Dumpsite Soils/ Nutrients}

Experiment conducted by an environmental student of Federal College of Land Resources Technology, Owerri [12] has shown the effect of solid waste (municipal waste) dumped on soil properties. The results indicated that soils from waste dumpsite have greater appreciable better chemical properties against those found in Non-waste dumpsite. This indicates the usefulness of some environmental waste as raw materials for organic fertilizers [12].

Waste dumpsite soils contain a number of favorable characteristic for agriculture such as macro-nutrients, micro-nutrients and some heavy metals heavy metals $[12,13]$. 


\section{Nitrogen (N)}

Nitrogen is one of the macro nutrients of the soil. Nitrogen is a key plant nutrient; crucial in forming nucleic acids and proteins, important for photosynthesis, cell wall composition, cell reproduction, energy and nutrient storage [14]. Nitrogen is a major macro-nutrient needed for growth and development of plants. It is fixed into the soil through the activities of nitrogen-fixing bacteria and some plants through their root nodules.

This important element exists in many forms in the soil system, transforming from one to another as influences by various complex chemical and biological processes [14]. Organic N, a component of soil OM in the form of decaying plant litter and soil organisms, and inorganic nitrate and ammonium are the most common forms of $\mathrm{N}$ found in the soil.

Nitrate is the preferable chemical from for the absorption of the plants. However, this is a very mobile chemical form. In order to minimize the rise of groundwater contamination, [15] recommended the use of stable organic amendments (with a more stabilized organic matter, which could produce a lower content of leachable Nitrogen forms. Risks are also minimized by planting rainfall crops and particularly choosing crops with a high demand for Nitrogen such as wheat or maize.

After the application of MSW compost to the soil, nitrogen is transformed into mobile forms, which can be accumulated in the soil, absorbed by plants, or released into the atmosphere or water system. The amount of nitrogen released into the soil solution determines the form of nitrogen availability to the plant and, consequently, the yield. If $\mathrm{MSW}$ is poor in nitrogen or the rate $\mathrm{C} / \mathrm{N}$ is inadequate for the mineralization of the organic matter, additional sources of nitrogen are need. [16] found that the low availability of compost- $\mathrm{N}$ means that supplementary nitrogen in the form of inorganic fertilizer may have to be added together with compost in order to enhance $\mathrm{N}$ availability to crops. They observed that inorganic fertilizer (NPK) and a mixture of MSW compost and inorganic fertilizer produce higher yields than MSW compost alone.

\section{Phosphorus}

Phosphorus is a fundamental crop macronutrient that is required by plants for early plant growth, development of reproductive organs, crop maturity and root development [17]. Phosphorus is a necessary component of key molecules in plant growth including nucleic acids, phospholipids and adenosine triphosphate (ATP). Therefore, plants need a consistent supply of $\mathrm{P}$ to reach their potential yield [18]. The $\mathrm{P}$ content of natural soil materials are usually less than $1 \mathrm{mg} \mathrm{kg}^{-1}[19,20]$.

A review paper by [21] on soil $\mathrm{P}$ dynamics reveals that, following $\mathrm{P}$ application in the form of manure, inorganic fertilizer and/or alternative organic products, plant available soil $\mathrm{P}$ increases as a function of physical and chemical soil properties. Specifically, theses plant available forms of $\mathrm{P}$ are most available within a $\mathrm{pH}$ range of 6-7 [22] and are influences by soil soluble Al, Fe, Ca and OM [21]

Various organic forms of $\mathrm{P}$ exists in the soil, representing $20-80 \%$ of the TP [18] and can symmetrically contribute to the P nutrition of plants [23]. The turnover of organic $\mathrm{P}$ in the soil is ultimately determined by both the rates of immobilization and mineralization [23]. 
Some authors observed that MSW compost effectively supplies phosphorus to soil with its concentration increased when increasing application rates. MSW composts provide equivalent amounts of phosphorus to soil as mineral fertilizers [24, 25].

Some reports observed that MSW compost provided equivalent amount of $\mathrm{P}$ to soil as mineral fertilizers. Low mineralization rates of $\mathrm{P}$ were seen immediately after application, but after a residence time of 3 months, MSW compost provided sufficient $\mathrm{P}$ for plant growth. A 10-50\% of total P in compost was available both the first and second year after application [26, 27]. I $\mathrm{n}$ an experiment in plots in a quarry restoration, where $3 \mathrm{~kg} / \mathrm{m} 3$ of MSW were applied to a substrate composed by limestone outcrop from the rejection of the quarry' an increment of nutrients associated to the composition of the composted MSW was obtained. In the plots in which MSW was applied' an important increase in the soil content of $\mathrm{N}$-Kjeldahl, available $\mathrm{P}$, and the rest of macro- and micronutrients was found, favouring the plant growth [28].

[29] studied the effect that 13 years of applying three different composted organic amendments have had on soil quality, Greenhouse Gas (GHG) emission, and the dynamics of its microbial communities 15 days after the annual application. They found that total Nitrogen increased with respect to the control by amending with organic fractions of Municipal Solid Waste. Organic amendment application resulted in higher levels of phosphorus and potassium in the soil. They concluded that significant higher organic matter contents, total $\mathrm{N}, \mathrm{P}$ and $\mathrm{K}$ contents, on the soil when compared to the control validate the fact that organic waste-based fertilizers contribute to enhanced soil fertility.

It has been reported that MSW compost has a high capacity to supply P to plants given the compost is mature since the concentration of $\mathrm{P}$ in MSW compost tended to increase with composting time. Some research suggested that excess $\mathrm{P}$ was applied to soil when MSW compost was applied to meet N requirements [30]. At high MSW compost application rates (>200 $\mathrm{Mgha}^{-1}$ ), to supply adequate $\mathrm{N}$, download movement of $\mathrm{P}$ was observed [31].

\section{Potassium (K)}

Potassium is another main source of nutrients for plant growth. A long-term study of MSW compost demonstrated that $\mathrm{K}$ was available in MSW compost as in mineral $\mathrm{K}$ fertilizers [26]. In a study conducted by [26, 27], of the total K in MSW compost, 36 - 48 $\%$ was found to be available for plant. Another study revealed that soil K concentrations are increased even when very low rates of MSW compost are used [32]. Increased K constant of the following was reported for soils treated with MSW compost. pp. blueberries, Swiss chard, boot-stage barley, alfalfa, and cock foot [33, 34, 35, 36, 37].

A study conducted by [38], Potassium level in the field soil was generally found to be high when enriched compost was applied to the field. Individual applications of enriched compost in the soil were observed to have maximum level potassium content, when compared to mineral fertilizer application alone. [34] have reported that potassium content in soil was increased with increasing dose of compost application.

[39] made similar observation that there was enhancement in soil available potassium content from the comparative studies on the effects of combining mineral fertilizers with compost materials with respect to those observed when mineral fertilizers alone were applied. [39] found that municipal waste leachate markedly increased the amount of available macro (N,P,K) and micronutrients ( $\mathrm{Fe}, \mathrm{Mn}, \mathrm{Zn}$ and $\mathrm{Cu}$ ) in soil and rice plant. 


\section{Effects of other Plant Essential Nutrients}

Some other essential plant nutrients or elements of interest and concern are. pp. calcium, magnesium, sulphur. A survey of selected MSW composts in the US found that Calcium, Ca was one of the major elements in the product, present at concentrations above $10 \mathrm{gkg}^{-1}$. Municipal Solid Waste compost has been reported to increase total and extractable soil $\mathrm{Ca}$ concentrations compared to fertilizer treatments [40]. Increased soil Ca concentrations, however, did not result in increased plant uptake of $\mathrm{Ca}$ by blueberries, Swiss chard, and basil (Ocimumbasilium L.) [35].

Furthermore a survey of MSW facilities in the U.S shared that the average Magnesium, $\mathrm{Mg}$ content of MSW compost was less than $5 \mathrm{gkg}^{-1}$, ranging from 1.8 to 4.4 $\mathrm{kg}^{-1}$ [41]. Municipal Solid Waste compost increased total soil $\mathrm{Mg}$ concentration when compared to an unamended control soil, which in turn increased Swiss chord and basil $\mathrm{Mg}$ concentrations [35]. Soil Mg concentrations were also increased when MSW compost was applied to a poorly drained soil when compared to control, fertilizer, gypsum and manure plots [37]. Magnesium concentrations in blueberry leaves were also seen to increase with MSW compost and that was proportional to the application rate [37].

In another study MSW compost was applied at $0,50,100$, and $150 \mathrm{~kg}$ plant available $\mathrm{Nha}^{-1}$ the first year (approximately, $0.75,150$, and $225 \mathrm{Mgha}^{-1}$ ), followed by half the amount the following year. His study found that soil $\mathrm{Mg}$ concentrations increased when compared to manure applications to barely $\mathrm{Mg}$ concentrations appeared to decline with increased compost addition and wheat $\mathrm{Mg}$ (Triticumaestivum, L) concentration rate but declined at the highest application rate [34].

In a study conducted by [31], MSW compost was found to increase soil sulphur, $\mathrm{S}$ concentrations, though the levels decreased with time probably due to the downward movement of the elements in the soil profile. However, other studies reveal fertilizer to be more effective in increasing soil S concentration when compared to MSW compost [42].

\section{Effect of pH (Soil Reaction)}

Perhaps the most outstanding characteristics of the soil solution is its reaction that is, the soil $\mathrm{pH}$. pH determines the amount of hydrogen present in a soil sample and ranges from $0-14$. Low $\mathrm{pH}$ indicated sour of soil. High $\mathrm{pH}$ is salty soil [43, 44]. Thus, acid soils have a pH below 7 and alkaline soils have a $\mathrm{pH}$ above 7 (Magdalene, 2017). The most important effect of $\mathrm{pH}$ in the soil is an ion solubility, which in turn affects microbial and plant growth [45].

A pH range of 6.0 to 6.8 is ideal for most crops because it coincides with optimum solubility of the most important nutrients. Some minor elements (e.g, Iron) and most heavy metals are more soluble at lower $\mathrm{pH}$. This makes $\mathrm{pH}$ management important in controlling movement of heavy metals (and potential groundwater contamination) in soil [46, 47]. Increased soil $\mathrm{pH}$ is considered as a major advantage when MSW compost is used [25] Low $\mathrm{pH}$ has been associated with the release of soluble $\mathrm{Al}$, which can inhibit root development. Low soil $\mathrm{pH}$ may also result in nutrient deficiency. Bases such as $\mathrm{Ca}, \mathrm{Mg}$, and $\mathrm{K}$ becomes more susceptible to leaching loss [48]. 


\section{Effect of Electrical Conductivity and Salt}

The amount of soluble salts in a sample is expressed in terms of electrical conductivity (EC) and measured by conductivity meter. Plants are negatively affected by excess salts in soils and $\mathrm{Na}$ can be detrimental to soil structure. Soil salination as a consequence of leachate disposal also implies exotexicological effects on plants and soil organisms [49].

Soil salination has negative effect on microbial respiration, especially when $\mathrm{Na}^{+}$ and/or $\mathrm{Cl}^{-}$are involved. Microbial activity and the cycling of nutrients may be inhibited. Furthermore, high salinity in newly restored sites may favour salt tolerant species and may alter the succession of the ecosystem [50].

[50] reported that besides minimizing the salt input by a proper dilution rate of leachate, the impact of salts can be reducing if salts were eluted away from the rooting zone. The traditional concept of leaching involves the pending of water to achieve more or less uniform salt removal from the entire soot zone [51].

[52] proposed the concept of leaching requirement. It is the excess amount of water in addition to evapotranspiration, required to leach salts out of the rooting zone to maintain an acceptable salt content. The volume of irrigation can be calculated based on evapotranspiration, salinity of the diluted leachate and the crop tolerance [50]. Leaching requirement (L.R) is given by [53].

$$
\mathrm{L} \cdot \mathrm{R}=\frac{E C w}{(5 E C e-E C w)}
$$

Where:

$\mathrm{ECw}$ is the electrical conductivity of irrigation water,

ECe is the average salt concentration of saturated extract. The depth of water required to leach the salts from the root zone is given by $\mathrm{D}_{\mathrm{a}}=\mathrm{ET} /(1-\mathrm{L} . \mathrm{R})$ where, $\mathrm{D}_{\mathrm{a}}$ represent the depth of water required to leach the salts and ET is the evapotranspiration rate [53].

Although the application of excess water can mitigate salination problem, plants would be severely impaired when the soil is water-logging with high salinity water, especially with leachate. Excessive water should be drained out of rooting zone. Moreover, planting salt-tolerant species (e.g Hibiscus tiliaceus) can lower the adverse impact to vegetation in episodic drought conditions due to hot dry weather or a breakdown of the irrigation system [50].

\section{Effect of Soil Organic Matter (OM)}

Estimates of soil organic matter are frequently based on organic carbon. The organic carbon content of soils includes the remains of plants, animals and micro-organism in all stages of decomposition. Carbon is a major element of soil organic matter that is readily measured quantitatively. Estimates of soil organic matter are frequently based on organic carbon. Values of organic carbon content of soils may be expressed in $5 \mathrm{or} \mathrm{g} / \mathrm{kg}$. Organic carbon can be converted to total organic matter by multiplying by the factor 1.729 . Soil containing less than 15 organic carbons is considered low in organic matter [12].

Several studies have revealed that the application of MSW compost increase soil organic matter content and soil $\mathrm{C} / \mathrm{N}$ ratio to levels greater than those of unamended soil $[54,55,56,36]$. 
Thus, Municipal Solid Waste compost had a high water holding capacity because of its organic matter content which in turn improved the water holding capacity of the soil (57].

Furthermore, application rates of 30 and $60 \mathrm{Mgha}^{-1}$ of MSW composts increased the aggregate stability of soil through the formation of cationic bridges thereby, improving the soil structure [57].

$[58,59]$ found that improved soil properties following that application lasted for several years and the quantity of microbial biomass $\mathrm{C}$ was greater for compost than control or inorganic fertilizer. [60] found higher soil OM levels in previously applied compost treatment plots than the control and OM levels increased with compost application rate.

\section{Soil Cation Exchange Capacity (CEC)}

A soil's CEC is the capacity for it to exchange of cations between it and its solution and is linearly related to the per cent clay and OM [22]. Cation exchange capacity is strongly correlated to soil electrical conductivity (EC), a measure of soluble ions (salts) in the soil, and Municipal Solid Waste compost application has been found to increase soil EC levels in relation to feedstock and facilities composting procedures. Other studies have identified soil EC levels to be related to application rates and that soil EC increases as more compost or manure is applied due to its high OM content [61, 62].

Exchangeable Cation (EC) is one of the important soil chemical properties which influence the soil fertility. Soil scientists are very interested in the cation exchange properties of soils because the distribution of the exchangeable cations indicates the relative abundance and availability of some major nutrient elements such as $\mathrm{Ca}, \mathrm{Mg}$ and $\mathrm{K}$ in soils. For Nigerian Soils, a cation content of about $2 \mathrm{Cmol} / \mathrm{kg}(2 \mathrm{meq} / 100 \mathrm{~g}$ soil $)$ is considered adequate for $\mathrm{Ca}$ and $\mathrm{Mg}$ while for $\mathrm{K}, 0.2 \mathrm{Cmol} / \mathrm{kg}(0.2 \mathrm{meq} / 100 \mathrm{~g}$ soil) and above is good [12].

\section{Effect of Iron}

The range of Fe that has been detected in MSW compost is $5.3-34.9 \mathrm{gkg}^{-1}$ according to a study by [32]. The application of MSW compost did not tend to increase soil and plant $\mathrm{Fe}$ contractions. In another study, MSW compost applied at 100 and 35-140 $\mathrm{Mgha}^{-1}$ did not increase available soil Fe concentration nor did clover and blueberry leaves, respectively, showed increase Fe concentration compared to a control [33].

\section{Effect of Micronutrients and Trace Elements (Heavy Metals)}

Most Municipal and Industrial wastes contain heavy metal. Heavy metal is used to cover a number of metals and their ions which are mostly of high density and belong largely to the group of "transition elements" of the periodic table. Some of these metals are also termed "Trace elements or Micro-nutrients" in agriculture stressing their relatively low abundance in normal soils. The fact is that they tend to be essential for plant growth [63].

The contamination of soil by heavy metal can cause adverse effects as human health, animals and soil productivity [64] and depending on the tendency of the contaminants, they end up either in water held in the soil matrix or leached to the underground water. 
Contaminants like Cadmium (Cd), Copper (Cu), Nickel (Ni), Lead (Pb) and Zinc (Zn) can alter the soil chemistry and have an impact on the organisms and plants depending on the soil for nutrition.

Research conducted by $[65,66,67,68,69,70]$ found out that plants grown on municipal dumpsites soil accumulated higher concentrations of the metals than those on rural dumpsites.

The studies further revealed that plants grown on dumpsites soils bioaccumulated higher metal concentrations than their counterparts obtained from normal agricultural soils.

\section{Composted Municipal Solid Waste (MSW) for Agricultural Purposes}

Compost is increasingly used in agriculture as a soil conditioner but also as fertilizer [71]. Composting MWS is seen as a method of diverting organic waste materials from landfills while creating a product, at a relatively low-cost that is suitable for agricultural purposes. Composting MSW reduces the volume of the waste, kills pathogens that may be present, decreases germination of weeds in agricultural fields and destroys malodorous compounds [72]. It used the biological system of microbes in the compost to breakdown or transform contaminants in soil/water [73].

When MSW compost was applied to soil at application rate of 20 and 80 Mgha-1, the major structural units of humic acid in MSW compost were incorporated into the humic acids in the soil [56]. The change in soil structure persisted and was structurally changed 9 years after the initial application [56]. Repeated application of MSW compost consistently increased soil organic matter content and soil $\mathrm{C} / \mathrm{N}$ ratio to levels greater than those of unamended soil $[54,55,56,36]$. Municipal solid waste compost had a high water holding capacity because of its organic matter content, which in turn improved the water holding capacity of the soil [57].

Furthermore, application of 30 and $60 \mathrm{Mgha}^{-1}$ of MSW compost increased the aggregate stability of soil through the formation of cationic bridge hereby improving the soil structure [57]. Another study also revealed that the addition of mature MSW compost in this case to a silt loam, increased aggregate stability [74].

Composting transforms organic by-products into drier, more uniform and biologically stable products that can act as slow-release sources of plant-available nutrients [75, 76]. MSW compost may consist of various combinations of household and/or commercial wastes including but not limited to. pp. food, kitchen and yard wastes, municipal sewage sludge, sawdust, paper products, biosolids, etc. municipal Solid Wastes (MSW) composed of about $45 \%$ of the wastes dumped in landfills [50]. Certain components of soil organic matter are largely responsible for the formation and stabilization of soil aggregates [77].

Finally, composting has seen well established and it is currently used to provide a final product, which can act as a soil conditioner or fertilizer. Compost contains major plant nutrients such as N, P, K and macronutrients [78, 79].

\section{Dumpsite soil Biological Properties/Microbial Activity}

Soil ecology is increasingly being used to evaluate soil quality. It is thought that soil microbial properties are most sensitive to changes in the soil environment [80, 81]. Biomass $\mathrm{N}, \mathrm{C}$, and $\mathrm{S}$ showed increases in the soil immediately, after compost addition are far up to 1 month, while biomass $\mathrm{P}$ showed an increasing trend for 5 months. 
Application of 2.5, 10, 20 and $40 \mathrm{Mgha}^{-1} \mathrm{MSW}$ compost increased soil microbial biomass $\mathrm{C}$ and soil respiration (an index of general metabolic activity of soil microorganisms) when compared to a control [82].

$[83,38]$ also observed that significantly higher amounts of total $\mathrm{N}$ and $\mathrm{C}$ and soluble organic carbon $\mathrm{C}$ which were found in the composts had the effect for increased microbial population. Another measure of soil microbial health is the activity of soil enzymes involved in the transformation of the principal nutrients [55].

\section{Dumpsite soils and plant growth}

Municipal solid waste compost is high in organic matter (OM) content, has a low bulk density [84], and research has shown that it has the ability to improve soil properties [25] and the growth and yield of vegetables $[60,33]$, with evidence of positive residual effects [85]. Soil organic matter also contains large quantities of plant nutrients that act as a slowrelease nutrient store-house, especially for nitrogen [9]. The use of composted organic wastes produces changes in soil physical, chemical, and biological properties and can enhance plant growth after its application [86].

Nutrient availability to plant is strongly influenced by organic and inorganic amendments that usually increase the amount of carbon and other nutrients, especially nitrogen. Organic matter is added to soil by the incorporating of plant materials, animal residue manure, sewage sludge or municipal waste. Amendments not only influence soil fertility, but can also affect the composition and activity of soil organisms [87]. [88] also reported that municipal solid waste has the ability of improving soils that have been cropped for many years, but which may be deficient in nutrients such as Boron, Zinc, Copper, and municipal solid waste compost mitigate such deficiencies. [89, 90] also added that crop residues contain considerable quantities of major crop nutrients as well as being source of organic matter.

The chemical properties of the waste material also have significant impacts on crop performance. For example, high nitrogen content favours fast-growing grass species which is often desirable for reclamation and revegetation projects [91]. Nevertheless, the application of composted waste to agricultural soils requires caution due to the possibility of food chain contamination and negative effects on soil microbiology, particularly rhizobia [91].

Studied, [71] the effect of Lunenburg's MSW compost on strawberries and concluded that it significantly increased soil Mehlich III extractable phosphorus (M3P) concentrations. These concentrations were found to increase with increasing MSW compost application rates. Fruit quality and yields were found to be reduced as a result of $\mathrm{N}$ deficient compost supplying inadequate amounts of $\mathrm{N}$ to the strawberries.

Positive residual effects from FYM and MSW composts have also been identified, such as increased soil organic matter (OM) content, nutrient availability and uptake by crops, and can be superior to those of residual manure and inorganic fertilizer applications. [34] investigated the residual effect of previous additions of MSW compost and found greater uptake by annual ryegrass and residual availability of $\mathrm{N}$ and $\mathrm{P}$ compared to previous manure applications. They also identified that repeated compost applications increased soil OM content and that grass yields increased with compost application rate [85]. 


\section{CONCLUSION}

Investigation of nutrients potentials of municipal solid waste compost, physicochemical soil properties at dumpsites and surrounding area were reviewed.

Definite patterns of higher values of soil properties at dumpsite soil than counterparts at surrounding or control soil were reviewed both in open dumpsites in developing and in developed economies.

Solid waste dumpsites have been reviewed to be rich in organic matter content which is the source of most of the nitrogen and phosphorus which enhances soil fertility and promote plant growth. The nutrients potentials of the dumpsite soils were reported to be higher in all works reviewed compared to the control locations. This may not be unconnected to the composition of the organic wastes which are mainly from agricultural and farmyard sources. Moreover, the activities of soil organisms in the decomposition of these wastes may have accounted for the rich nutrient contents of the dumpsite soils compared to the natural soils (control locations).

This review buttresses the fact that Composts represent an important resource to maintain and restore soil fertility, especially in those areas/ fields or soils where the organic matter contents have declined. However, the application of composted waste to agricultural soils requires caution due to the possibility of food chain contamination and negative effects on soil microbiology, especially rhizobia.

\section{REFERENCES}

[1] He, X., Traina, S. J. and Logan, T. J. 1992. Chemical properties of municipal solid waste. Journal of Environmental Quality 21, pp.318-329.

[2] Cook, B. D., Halbach, T. R., Rosen, C. J. and Moncrief, J. F. 1994. Effect of a waste stream component on the agronomic properties of municipal solid waste compost. Compost Science and Utilization 2, pp. 775-87.

[3] Erikson, G, Coak,F ,Bollero, G, 1999. Soil nitrogen dynamics and maize production in municipal solid waste amended soil. Argon. Journal. 91, pp. 1009 - 1016.

[4] Wolkowski, R.(2003). Nitrogen management considerations for land spreading municipal solid waste compost. Journal of Environ. Qua., 32. pp. 1844 - 1850.

[5] Iglesias - Jimenez, E., Awarez, C. 1993. Apparent availability of nitrogen in composted municipal refuse. Biol. Fert. Soils, 16. pp. 313 -318.

[6] Weber J, Kocowicz A, Bekier J, Jamroz E, Tyszka R, Debicka M, et al. 2014. The effect of a sandy soil amendment with municipal solid waste (MSW) compost on nitrogen uptake efficiency by plants. European Journal of Agronomy,54. pp. 54- 60.

[7] Adelekan, B. A. and Alawode, A. O. 2011. Contributions of municipal refuse dumps to heavy metals concentrations in soil profile and groundwater in Ibadan Nigeria. Journal of Applied Biosci., 40. pp. 2727-2737.

[8] Bolan, N. S. A., Szogi, A. A., Chusavathi, T., Seshadri, B., Rothrock Jr., J. and Panneerselvam, P. 2010. Uses and Management of Poultry Litter. World's Poultry Science Journal, 66(4). pp. 673-698.

[9] Shulan Zhao, Xiaobo Liu, Lian Duo 2012. Physical and chemical characterization of municipal solid waste compost in different particle size fractions. Pollution Journal of Environmental studies, 21(2). pp. 509-515. 
[10] Piccolo, A. and Mbagwu, J. S. 1990. Effects of different organic waste amendments on soil micro aggregate stability and molecular sizes of humic substances.

Plant Soil, 123. pp.27-37.

[11] Shiralipour, A., McConnell, D. B. and Smith, W. H. 1992. Physical and Chemical Properties of Soils as affected by Municipal Solid Waste Compost Application, Bioenergy. 3(3-4), pp. 261-266.

[12] Ufot, U. O., Iren O. B. and Chikere Njoku. 2016. Effects of lanf use on soil physical and chemical properties in Akokwa Area of Imo State, Nigeria. International Journal of Life Science and Scientific Resources, 2(3). pp. 273-278.

[13] Sokka, L., Antikainen, R., Kauppi, P. 2004. Flows of nitrogen and phosphorus in municipal waste. pp. A substance flow analysis in Fui land. Prog. in ind. Ecology. 1(1-33), pp. $165-186$.

[14] University of Missouri (Univ. of Miss.).1993. Agriculture nutrient management publications. Available fro. pp.http. pp.//extension.missouri.edu/main/DisplayCategory.aspx. Accessed on February 2o, 2021.

[15] Perego, A., Basile, A., Bonfante, A. DeMascellis, R., Terribite, F. and Brenna. 2018. Nitrate leaching under maize cropping systems in Po valley (Italy). Agriculture, Ecosystems and Environment, 147, pp.57-65.

[16] Jorge-mardomnigo, I., Jimenez, M. E., Moreno, L.,de-la-losa, A., de-la-Cruz, M. T., Casermeiro, M. E., Moreno, L. 2015. High doses of organic amendments in a Mediterranean of agricultural soil. pp. An approach for assessing the risk of ground water contamination. Catena. 131, pp. $74-83$.

[17] Karemangingo, C. 2004. Environmental issue associated with phosphorus in New Brunswick. Available from. pp.http. pp.//www.gnb.ca/0173/30/017300016-e.asp. Accessed on September 30, 2008.

[18] Schachtman, D. P., Reid, R. j. and Ayling, S. M. 1998. Phosphurus uptake by plants. pp. from soil to cell. Plant physiol. 116, pp. 447-453.

[19] Jim C. Y. 1996. Edapjic properties and horticultural applications of some common growing media. Communications in Soil Science and Plant Analysis 27. pp.2049-2064.

[20] Lefebvre, A., Eilers, W. and Chunn, B. 2005. Environmental Sustainability of Canadian Agriculture. pp. Agri-Environmental Indicator Report Series-Report \#2. Agriculture and Agri-Food Canada, Ottawa, Ontario.

[21] Sharpley, A. 1995. Soil phosphorus dynamics. pp. agronomic and environmental impacts. Ecol. Eng. 5. pp.261-279.

[22] Burton, D., Fairchild, G., Brewster, G., Main, M., Miller, C., Miller, M. and Leblanc, L. 2003. Nutrient Management Planning Booklet. Nova Scotia Agricultural College.

[23] Condron, L.M., Turner, B. L. and Cade-Menum, B. J. 2005. Chemistry and Dynamics of Soil Organic Phosphorus. Pages 87-121. In. pp. J. T. Sims and A. N. Sharpley (eds). 2005. Phosphorus. pp. Agriculture and the Environment. American Society of Agronomy, Agonomy Monograph No. 46.

[24] Canadian Fertilizer Institute . 2001. Mutient uptake and removal by field crops. pp. eastern Canada. Available from: //www.mbforagecouncil.mb.ca/CustomBlox/Files/Live/Blox/776/5.45_CFI_Nutrient_ Uptake_for_ECanada.pdf. accessed on May 10, 2021.

[25] Mkhabela, M.S. and Warman, P. R. 2005. The influence of municipal solid waste compost on yield, soil phosphorus availability and uptake by two vegetable crops grown in a pugwash sandy loam soil in Nova Scotia. Agriculture, Ecosystem and Environment, 106. pp. 57-67.

[26] DeHaan, S. 1981. Results of municipal waste compost research over more than fifty years at the Institute for Soil Fertility at Haren/Groningen, the Netherlands. Netherlands. Journal of Agric., 29, pp. 49-61. 
[27] Soumare, M., Tack, F., Verloo, M., 2003. Characterization of Malian and Belgian solid waste composts with respect to fertility and suitability for land application. Waste management, 23 , pp. 517-522.

[28] Jordan M. M, Garcia-Sanchez E., Almendro-Candel MB, Navarro-Pedreno J., Gomez-Lucas I. Melendez I. 2009. Geological and environmental implications in the reclamation of limestone quarries in Sierra de Callosa (Alicante, Spain). Environmental Earth Sciences, 59, pp.687-694.

[29] Calleja-Cervantes ME, Fernandez-Gonzalez AJ, Irigoyen I., Fernandez-Lopez M., AparicioTcjo PM, Menendez S.2015. Thirteen years of continued application of composted organic wastes in a vineyard modify soil quality characteristics. Soil Biology and Biochemistry.

[30] Bar-Tal, A., Yermiyahu, U., Beraud, J., Keinan, M., Rosenberg, A. R., Zohar, D., Rosen, V, Fine, P. 2004. Nitrogen, Phosphorus, and Potassium uptake by wheat and their distribution following successive, annual compost applications. Journal Environ. Qual. 33,pp. 1855-1865.

[31] Zhang, M., Heaney, D., Henriquez, B., Solberg, E., Bittner, E. 2006. A four- year study on influence of biosolids /MSW compost application in less productive soils in Alberta. Nutrient Dynamics of Compost Sci. Util., 14 (1), pp. 68 - 80.

[32] Giusquiani, P., Marucchini, C. Businelli, M. 1988. Chemical Properties of soils amended with compost of urban waste. Plant soil, 109,pp. 73-78.

[33] Warman, P. R., Rodd, A. V. and Hicklenton, P. (2009). The effects of MSW compost and fertilizer on extractable soil elements and the growth of winter squash in Nova Scotia. Agric. Ecosyst. Environ. 133, pp.98-102.

[34] Rodd, A., Warman, P.R., Hickleton, P.,Webb, K. 2002. Comparison of N fertilizer, sourceseparated municipal solid waste compost and semi-solid beef manure on the nutrient concentration in boot-stage barley and wheat tissue. Can. Journal of Soil Science . 82, pp. 33-43.

[35] Zheljazkov, V. Warman, P. R. 2004a. Source-separated municipal soil waste compost application to Swiss chard and basil. J. Environ. Qual. 33, 542-552.

[36] Montemurro, F., Maiorana, M., Converting, G., Ferri, D. 2006. Compost organic amendments in fodder crops. Effects on yield, nitrogen utilization and soil characteristics. Compost Sci. Util.10, pp. $114-123$.

[37] Zheljazkov, V., Astatkie, T., Caldwell, C. D. Macleod, J. and Grimmett, M. 2006. Compost, manure, and gypsum application to timothy/red clover forage. Journal of Environ. Qual., 35. pp. 2410-2418.

[38] Kavitha, R. and Subramanian, P. 2007. Effect of enriched municipal solid waste compost application on growth, plant nutrient uptakeand yield of rice. Journal of Agronomy, 6(4), pp. 586-592.

[39] Khoshgoftarmanesh, A. H. and Kalbasi M. 2007. Effect of Municipal waste leachate on soil properties and growth and yield of rice. Communications in Soil Science and Plant Analysis, 33. pp.13-14.

[40] Shanmugan, G. S. 2005. Soil and plant response of organic amendments on Strawberry and half-high blueberry cultivars. Master's Thesis. Dalhousie University, Halifax, Nova Scotia, Canada.

[41] He, X., Logan, T., S. 1995. Physical and chemical characteristics of selected U.S. municipal solid waste composts. Journal of Environ. Qual., 24. pp. 543 -552.

[42] Shanmugan, G. S. and Warman, P. R. 2004. Soil and plant response to organic amendments to three strawberry cultivars. In. pp. Martin-Neto, L., Milori, D. da Silva, W. (eds), Proceedings of the International Humid substances Society. Embrapa (Pub.), Sao Pedro, pp. 230-232.

[43] Manikandan, R. 2016. Physio-chemical analysis of marine soil from different ecosystem Tamil Nadu, India. International Journal of Soil Science, 6, pp. 100-204. 
[44] Magdalena Daria Vaverkova . 2017. Environmental impact of landfill on soils. pp. The example of the Czech Rebublic. Polish Journal of Soil Science, 50(1), pp. 93.

[45] Udoumoh, U. I. , Antia O. O., Ahuchaogu, I. I., Ehiomogue, P. O., Sam, E. M. 2020. Analysis of some soil characteristics of gully erosion sites across different land areas of Uyo, Nigeria. Journal of research and innovations in Engineering, Faculty of engineering, university of Uyo, volume 5, No 2, pp. 333-340.

[46] Eze, E. B. and Effiong, I. 2010. Morphometric parameters of the Calabar River Basin; implication for Hydrologic processes. J.of Geography and Geology, 1(2). pp. 18-26.

[47] Danladi, A. \& Ray, H. H. 2014. An Analysis of some soil properties along gully erosion sites under different land use araeas of Gombe metropolis, Gombe State, Nigeria.Academic Journals .vol. 7., pp.86-96.

[48] Marschner, P. 2012. Marschner"s Mineral Nutrition of Higher Plants. 3rd edition (London. pp. Academic Press).

[49] Kulkarni A. N. 2011. Studies of physicochemical factors of teak forest area from Kinwat, Nanded. Journal of Soil Science, 5, pp. 437- 438.

[50] Chen Y X, Zhou D W, Zhang Y F. 2004. Temporal and spatial variations of chemical constituents in maize. Chinese Journal of Applied Ecology, 15, pp. 1589-1593. (in Chinese)

[51] Schwab G. O., Fangmeier, D. D., Elliot, W. J and Frevert, R. K. (1993). Soil and Water Conservation Engineering. John Willey and Sons, Inc. New York.

[52] Ayers R. S. and Westcot DW. 1985. Water quality for agriculture, FAO irrigation and drainage paper 29. Food and Agriculture Organization of the United Nations.

[53] Suresh, R. 2006. Soil and Water Conservation Engineering. Standard publishers Distributors. Delhi, pp. 110-006.

[54] Perucci, P.1990). Effect of municipal solid - waste compost on microbial biomass and enzyme activities in soil. Biol. Fertile Soils, 10, pp. $221-226$.

[55] Crecchio, M., Pizzigallo, M., Ricciuti, P., Ruggiero, P. 2004. Effects of municipal solid waste compost amendments on soil enzyme activities and bacterial genetic diversity. Soil Biol. Biochem., 36, pp. $1595-1605$.

[56] Garcia-Gill, J. C., Cepi, S., Velasca, M., Polo, A., Sensi, N. 2004. Long term effect of amendment with municipal solid waste compost on the elemental and acid functional group composition and $\mathrm{pH}$ buffer capacity of soil humid acid. Geoderma. 121(1). pp. $135-142$.

[57] Hernando, S., Lobo, M. and Polo, A. 1989. Effect of the application of municipal refuse compost on the physical and chemical properties of soil. Sci. Total Environ., 81/82, pp. 589-596.

[58] Graham M. H., Hynes, R. I. and Meyer, J. H. 2002. Soil organic matter content and quality. pp. effects of fertilizer applications, burning and trash retention on long-term sugarcane experiment in South Africa. Soil Bio. Biochem. 34, pp.93-102.

[59] Avnimelech, Y., D., Shkedy, M., Kochva, and Yotal. Y. 1994. The use of compost for the reclamation of saline andalkaline soils. Compost Science \& Utilization, 2(3). pp.6-11.

[60] Ozones-Hampton M., Stoffella, P. J., Bewick, T. A.,Canlette, D. J. and Obreza, T. A. 1999. Effect of age of co-comported MSW and bio solids on weed seed germination. Compost Science and Utilization, 7. pp.51-57

[61] Eghall, B. 2002. Soil Properties as influenced by phosphorus and nitrogen-based manure and compost applications. Agron. J. 94; pp.128-135.

[62] Eghall, B., Ginting, D. and Gilley, J. E. 2004. Residual effects of manure and compost applications on corn production and soil properties. Agron. J. 96, pp.442-447.

[63] Voutsa D., Grimanis A., Samara C. 1996). Trace elements in vegetables grown in an industrial area in relation to soil and air particulate matter. Environ Pollut 94, pp.325-335. 
[64] Smith F. W and Loneragan J.F.1997. Interpretation of plant analysis. pp. concepts and principles. In. pp. Reuter DJ and Robinson J. B., editos. Plant Analysis. pp. An interpretation manual, $2^{\text {nd }}$ edition. Australian Soil and Plant Analysis Council Inc. pp 3-33. CSIRO Publishing, Collingwood.

[65] Pescod, M. 1992. Wastewater Treatment and use in Agriculture, FAO Irrigation and drainage paper 47. Rome. pp. Food and Agriculture Organization.

[66] Ideriah, TJK; Harry, FO; Stanley, HO; Igbara, J.K. 2010. Heavy metal contamination of soils and vegetation around solid waste dumps in Port Harcourt, Nigeria. Journal of Applied science and Environmental Management, 14(1), pp.101-109.

[67] Ebong, G. A.,; Etuk, Helen, Johnson Atim. 2007. Heavy metals accumulation by Talinum triangular grown on waste Dumpsites in Uyo metropolis, Akwa Ibom State, Nigeria. Journal of Applied Sciences, pp. 1404-1409.

[68] Buczko, U. K.,Ucherbuch, R.O., Len, Artz, B. 2010. Assessment of predictive quality of simple indicator approaches for nitrate leaching from agriculture fields. Journal of Environmental Management, 91, pp. $1305-1315$.

[69] Ugwu, E. C. 2019. Remediation of contaminated soil in copper mining areas using plant-based surfactants. Unpublished research Thesis submitted for the degree of Doctor of Philosophy, School of Energy, Geoscience, Infrastructure and society (EGIS), Heriot Watt University, United Kingdom.

[70] Bowie S. H and Thornton I. 1985. Environmental Geochemistry and Health. Report to the Royal Society's British National Committee for problems of the environment. Springer Link. Part of the GeoJournal Library book series (GEJL) . Vol. 2, pp.1-130

[71] Hargreaves, J. C., Adi, M. S., Warman, P. R., Murphy, C., Burnham, J. and Eaton, L. 2007. Soil and plant response to MSW compost applications on lowbush blueberry fields in 2000 and 2001. Small Fruit Rev., 3(1/2), pp. 19-31.

[72] Jakobsen, S. 1995. Aerobic decomposition of organic wastes 2. Value of compost as fertilizer. Resour. Conserve. Recy., 13, pp. 57 -71.

[73] USEPA. 1997. United State Environmental Protection Agency. United State Environmental

Protection Agency. pp. http. pp.//www.epa.gov/osw/conserve/rrr/composting/pubs/bioremed.pdf.

(Retrieved on June 15, 2020).

[74] Annabi, M., Nouot, S., Francou, C. Poitrenaud, M. and LeBissonnais, Y. 2007. Soil aggregate stability improvement with urban composts of different maturities. Soil Sci. Soc. of Am. Journal, pp. 413-423.

[75] Almendro-Candel, M. B., Navarro-Pedreno, J., Jordan, M. M., Gomez,I. and MetendezPastor,I. 2014. Use of municipal solid waste compost to reclaim limestone quarries mine spoils as soil amendments. Effect on Cd and Ni. J. of Geochemical Exploration, 11, pp. 2-12.

[76] Sullivan, D. M., Bary, A. I., Nartea T. J., Myrhe, E. A., Cogger, C. G. and Fransen, S. C. 2003. Nitrogen availability seven years after a high-rate food waste compost application. Comp. Sci. Utility 11, pp.265-275.

[77] Swife R. S. 2001. Sequestration of carbon by soil. Soil Sci. 166, pp. 858.

[78] EU Directive for sewage sludge 2000. Council/ Directive 86/2781/EEC.

[79] USEPA (2003). Environmental and Economic Benefit Analysis of Final Revisions to the National Pollutant Discharge Elimination System Regulation and the Effluent Guidelines for Concentrated Animal Feeding Operations.

[80] Pankhurst, C. E., Doube, B.M., Gupta, V.V.S. R. 1997. Biological indicators of soil health. CABI, Walhingford, United Kingdom, 451p.

[81] Crecchio, C., Curci, M.,Mininni, R.,Ricciuti, P., Ruggiero, P. 2001. Short term effects of municipal solid waste compost amendments on soil carbon and nitrogen content, some enzyme activities and genetic diversity. Biology and Fertility of Soils, 34, pp.311 - 318. 
[82] Bhattacharyya, P., Chakrabarti, K., Chakraborty, A. (2003a). Effect of MSW compost on microbiological and biochemical soil quality indicators. Compost Sci. Util. 11(3), pp. $220-227$.

[83] Zaman M., Matsushima M., Chang S., Inubushi K., Nguyen L. Goto S., Kanek O.F, Yoneyama T. 2004. Nitrogen mineralization, $\mathrm{N}_{2} \mathrm{O}$ production and soil microbiological properties as affected by long-term application of sewage sludge composts. Bio Fertile Soils 40, pp.101-109.

[84] Dermatas, D.,Chrysochoou, M. 2007. Lead particle size and its association with firing conditions and range maintenance. Implications for treatment. Environ. Geochem. Health, 29, pp. p.347.

[85] Rodd, V., Warman, P., Webb, K. and Hicklenton, P. 2002. The Residual Effect of Previous Additions of Source-Separated Municipal Solid Waste compost and manure on the yield of annual Ryegrass. Report for Agriculture and Agri-Food, Canada, Charlottr town, PEI.

[86] Civeira, G. 2010. Influence of municipal solid waste compost on soil properties and plant reestablishment in peri-urban environments.Chilean. Journal of Agricultural Research, $70(3)$, pp. $446-453$.

[87] Carmine Crecchio, Magda Curci, Maria D. R, Pizzigallo, Patrizia Riccicutti, PaciFCo Ruggiero .2004. Effects of Municipal Solid Waste compost Amendments on SoilEnzyme Activities and Bacteria Genetic Diversity. International Letters of Natural Sciences Vol. 29, pp. 1595-1605.

[88] Peter B. Woodbury . 2005. Municipal Solid Waste composting potential effects of Heavy metal in Municipal Solid Waste compost and the environment. Boyce Thompson Institution for Plant Research at Cornell University. Municipal Solid Waste Fact Sheet 4 of 7.

[89] Stangel P. J. 1995. Nutrient cycling and its importance in sustaining crop-livestock system in Sub-Sahavah Africa. pp. An overview. In Powell J.M. Fernandez - Rivera. S.,Williams T.O, and Nutrient cycling in mixed Farming systems of Sub-Sahara Africa, pp. 37-62.

[90] Agboola A. A., International Board for sol Research and Management 10. 1990, pp.23-244.

[91] Glanville, T. D., Persyn,R. A., Richard, T. I., Laflen, J. M. and Dixon, P. M. 2004. Environmental effects of applying composted organics to new highway embankments. Part 2, Water quality. Transaction of the American Society of Agricultural Engineers, 47(2), pp.471-478.

\title{
PREGLED HRANLJIVIH POTENCIJALA KOMPOSTIRANOG KOMUNALNOG OTPADA ZA UPOTREBU U POLJOPRIVREDI
}

\author{
Iniobong U. Udoumoh ${ }^{1}$, Josiah M. Ayotamuno ${ }^{2}$, Israel I. Ahuchaogu ${ }^{1}$ \\ ${ }^{1}$ Department of Agricultural and Food Engineering, University of Uyo, Uyo, Nigeria. \\ ${ }^{2}$ Department of Agricultural Engineering, Rivers State University of Science \\ and Technology, Port Harcourt, Nigeria
}

Sažetak. U radu je prikazana primena komposta za biljke u obezbeđivanju najvažnijih makronutrijenata. pp. azota $(\mathrm{N})$, kalijuma $(\mathrm{K})$ i fosfor $\mathrm{a}(\mathrm{P})$, i mikronutrijenata, kao. pp. gvožđa $(\mathrm{Fe})$, magnezijuma $(\mathrm{Mg})$, bakra $(\mathrm{Cu})$, cinka $(\mathrm{Zn})$ i bora $(\mathrm{B})$ i poboljšavanju mikrobne aktivnost. 
Hranljive materije se sporo oslobađaju zbog jake povezanosti komposta sa organskom materijom. Ova osobina predoređuje kompost za odlično alternativno neorgansko đubrivo jer su smanjeni mnogobrojni gubici ispiranja određenih sastojaka.

Prekomerna upotreba hemijskih đubriva povezana je sa promenom (padom) dobrih (povoljnih) vrednosti papametara fizičkih i hemijskih osobina zemljišta i prinosa useva, kao i značajnim problemima zemljišta, kao što je degradacija usled prekomerne eksploatacije i zagađenja zemljišta prouzrokovano visokim procentima primene hemijskih đubriva i neogovornom primenom pesticida.

Smanjenje upotrebe hemijskih đubriva i dopuna putem organskog đubriva kao što je gradski kompost, koji se dobija od komunalnog čvrstog otpada (KČO), i đubriva sa farmi krupnih životinja (FKŽ), ili farmi živine (FŽ), i slično, postaju neophodna za održavanje. produktivnosti, profitabilnosti i dobrog zdravlja zemljišta.

Primena (FKŽ), praktikuje se dugi niz godina, ali postaje sve ređe zbog oskudnog ili smanjenog stočnog fonda.

Zato je kompost od komunalnog čvrstog otpada (KČO), jedan od dobrih alternativnih izvora organskih đubriva.

Ključne reči: Hranljive materije, organska materija, komunalni čvrsti otpad, kompost, prinos useva

Prijavljen.

Submitted..

01.07.2021

Ispravljen.

Revised

12.08.2021.

Prihvaćen.

Accepted

21.09.2021. 